\title{
PEMUTUSAN HUBUNGAN KERJA PADA PERUSAHAAN PAILIT
}

\author{
Mashudi*, Hamdi Aji** \\ * Fakultas Hukum, Universitas Gresik \\ Email : mashudiunigres@gmail.com \\ ** Fakultas Hukum, Universitas Gresik \\ Email : hamdiajiaji@gmail.com
}

\begin{abstract}
ABSTRAK
Membahas pemutusan hubungan kerja pada perusahaan yang pailit yang diatur dalam peraturan perundang-undangan tentang kepailitan juga ketenagakerjaan juga mengenal sejahu mana jaminan pembayaran upah atau uang pesangon bagi pekerja/buruh dalam suatu perusahaan yang dinyatakan pailit dapat dijamin. Dengan demikian dapat mengetahui kemungkinan dapat didahulukan hak buruh terhadap kedudukan hak-hak lain dallam kepailitan. Metode yang digunanakan adalah normatif berdasarkan Undang-Undang ketenagakerjaan dan Undang-Undang kepailitan,yang kemudian untuk menggambarkan secara tepat tentang kedudukan buruh dalam proses pemutusan hubungan kerja akibat kepailitan.
\end{abstract}

Kata Kunci : Buruh, Pemutusan hubungan kerja, pailit.

\begin{abstract}
Discussing the termination of employment at a bankrupt company that is regulated in the legislation regarding bankruptcy as well as employment also knows how far the guarantee of payment of wages or severance pay for workers I laborers in a company that is declared bankrupt can be guaranteed. Thus it can find out the possibility of giving priority to labor rights to the position of other rights in bankruptcy. The method used is normative based on the Manpower Act and the Bankruptcy Act, which is then to describe precisely the position of workers in the process of termination of employment due to bankruptcy.
\end{abstract}

Keywords : Laborers, work termination, bankruptcy. 


\section{A. Pendahuluan}

\subsection{Latar Belakang}

Perkembangan masyarakat dunia yang cepat dan kebutuhan manusia yang meningkat seiring dengan perkembangan teknologi dan budaya mempengaruhi perilaku masyarakat itu sendiri. Adanya persaingan yang tajam dalam era globalisasi mengharuskan pengusaha di indonesia yang ingin tetap bertahan untuk terus melakukan langkah-langkah guna mempertahankan usaha dan bisnisnya.Kenyataan bahwa dalam menjalankan operasionalnya, perusahaan tidak selalu menunjukkan perkembangan dan peningkatan laba (profit), "sebab risiko yang dapat timbul dari bisnis, baik itu risiko investasi, risiko pembiayaan dan risiko operasi. Semua risiko dapat mengancam kesinambungan dari keuangan perusahaan dan yang paling fatal perusahaan bisa mengalami bangkrut (pailit) karena tidak bisa membayar semua kewajiban utang perusahaannya.

Dalam menjalani sebuah perusahaan "pengusaha memerlukan tenaga kerja untuk dapat membantu mengoperasionalkan perusahaannya untuk mendapatkan keuntungan. Pada kenyataannya adakalanya permasalahan itu datang dan perusahaan mengalami krisis keuangan. Jika perusahaan mengalami kerugian yang menyebabkan perusahaan tidak dapat memenuhi kewajibannya untuk membayar utangnya kepada para kreditur yang merupakan salah satu faktor terjadinya perusahaan pailit.

Dalam permasalahan perusahaan pailit pengusaha akan sulit untuk melakukan pembayaran yakni mengenai kewajibannya kepada para pekerja berupa gaji-gaji pekerja dan utang-utangnya kepada para kreditur yang wajib dipenuhi setelah pekerja mengalami Pemutusan Hubungan Kerja (PHK).

Termuat dalam Pasal 95 ayat (4) Undang-Undang Nomor. 13 Tahun 2003 tentang Ketenagakerjaan (UU Ketenagakerjaan) yang intinya bahwa pekerja sebagai kreditur preferen yang mendapatkan pembayaran haknya dengan mendahului semua kreditur. Namun, dalam perusahaan pailit yang telah diatur dalam Undang-Undang Nomor.37 Tahun 2004 tentang Kepailitan dan Penundaan Pembayaran Utang (UU Kepailitan Baru) tidak memperjelas dan mempertegas mengenai kedudukan hak pekerja terhadap utang gaji yang didahulukan pembayarannya dari kreditur lainnya. Sehingga terdapat ketidakpastian hukum bagi pekerja dalam meperoleh hak-haknya. Oleh karena itu dilakukan permohanan uji materiil kepada Mahkamah Konstitusi terhadap Pasal 95 ayat (4) UU Ketenagakerjaan terhadap penafsiran didahulukan pembayrannya. Dengan diberikan penafsiran terhadap Pasal 95 ayat (4), maka dapat memberikan kepastian hukum terhadap hak pekerja yakni khususnya gaji yang merupakan hak dasar bagi para pekerja yang bekerja pada suatu perusahaan dan dalam penafsiran ini dapat memberikan kedudukan yang jelas terhadap pekerja sebagai kreditur preferen yang memiliki hak istimewa yang didahulukan pembayarannya dari kreditur lainnya.

Merujuk dari definisi atau kententuan umum dalam Pasal 1 ayat 
1 UU Nomor 37 Tahun 2004 tentang Kepailitan dan Penundaan Kewajiban Pembayaran Utang, di mana kepailitan adalah sita umum atas semua kekayaan debitor pailit, maka orang individu atau 'korporasi termasuk korporasi yang berbentuk badan hukum maupun yang bukan badan hukum yang mempunyai utang semua kekayaannya disita. Apabila debitor di nyatakan pailit, maka banyak akibat yuridis di berlakukan kepadanya oleh Undang-Undang, salah satunya adalah terhadap perjanjian-perjanjian yang berkelangsungan antara debitur dengan pihak lain yaitu pekerja atau buruh.

Berdasarkan latar belakang tersebut maka penulis bisa mendapatkan ide untuk membuat skripsi dengan judul "PEMUTUSAN KERJA PADA PERUSAHAAN PAILIT".

\subsection{Rumusan Masalah}

Berdasarkan uraian latar belakang permasalahan di atas, maka rumusan masalah dalam penelitian ini adalah:
a. Bagaimana pemutusan hubungan kerja pada perusahan yang mengalami pailit menurut Undang- Undang Nomor 13 Tahun 2003 Tentang
Ketenagakerjaan?

b. Bagaimana hak pekerja yang terjadi pemutusan hubungan kerja akibat perusahaan pailit?

\subsection{Tujuan Penelitian}

Adapun tujuan penelitian yang ingin diperoleh dari hasil penelitian ini adalah sebagai berikut : a. Penelitian ini bertujuan mengetahui bagaimana media penyelesaian pemutusan hubungan kerja pada perusahan yang mengalami pailit menurut Undang-undang Nomor. 37 tahun 2004 tentang kepailitan.

b. Penelitian ini bertujuan bagaimana penyelesaian hak pekerja pada perusahan pailit menurutUndang-Undang

Nomor. 13 tahun 2003 tentang ketenagakerjaan.

\subsection{Manfaat Penelitian}

Manfaat dari penelitian ini adalah:

\section{a. Secara Teoritis}

Hasil penelitian ini diharapkan dapat memberikan sumbangan pemikiran dan memperkaya khasanah ilmu hukum, terutama Hukum Ketenagakerjaan dan Hukum Kepailitan yang berkaitan dengan . akibat hukum putusan pailit terhadap pekerja yang mengalami pemutusan hubungan kerja.

\section{b. Secara Praktis}

Hasil penelitian ini diharapkan dapat menyumbangkan pemikiran terhadap pemecahan masalah dan sebagai bahan masukan atau referensi bagi pembaca atau praktisi dalam melakukan bagai mana penyelesaian hak pekerja pada perusahaan pailit menurut UndangUndang Nomor 13 tahun 2003 ketenagakerjaan.

\subsection{Metode Penelitian}

1.4.1 Jenis Penelitian 
Jenis penelitian pada tugas akhir ini menggunakan jenis penelitian hukum normatif (normative legal research). Jenis penelitian hukum normatif ini dilakukan dengan mengkaji peraturan perundangundangan, teori-teori hukum dan pendapat ahli yang berhubungan dengan masalah yang akan dibahas.

\subsubsection{Metode Pendekatan}

Sehubungan dengan tipe penelitian yang digunakan yakni metode penelitian hukum normatif, maka pada penelitian tugas akhir ini peneliti menggunakan tiga jenis pendekatan, yaitu pendekatan peraturan perundang-undangan (statute approach), pendekatan konseptual (conceptual approach), pendekatan sejarah (historical approach).

\subsubsection{Sumber Bahan}

\section{Hukum}

Penelitian ini membutuhkan 2 (dua)jenis data. Data yang akan dikumpulkan adalah data primer dan data sekunder.

a. Sumber Hukum Primer adalah sumber bahan hukum yang diperoleh dari aturan-aturan hukum, kitab undang-undang hukum perdata, undang-undang, peraturan

pemerintah, dan aturan lain dibawah undang-undang yang berkaitan langsung dengan masalah ketenagakerjaan dan kepailitan.

b. Sumber Hukum Sekunderadalah sumber hukum yang diperoleh dari semua publikasi tentang hukum, pendapat para sarjana, kasus-kasus hukum yang terkait dengan pembahasan, buku-buku yang memberikan penjelasan mengenai bahan hukum primer.

\subsection{PEMBAHASAN}

\subsubsection{Pemutusan hubungan kerja yang disebabkan Karena Pailit.}

Pengusaha dapat melakukan PHK terhadap pekerja /buruh karena perusahaan pailit (bangkrut). Pernyataan pailit ini harus ditetapkanberdasarkan putusan pengadilan niaga pada peradilan umum berdasarkan Undang-Undang No. 37 Tahun 2004 tentang Kepailitan dan Penundaan Kewajiban Pembayaran Utang. Pemutusan hubungan kerja tersebut tertuang pada pasal 39 ayat 1 dan 2 .

\subsubsection{Undang-Undang Tentang Penyeleian Perselisihan Hubungan Industri}

1. Perselisihan Hubungan Industrial adalah perbedaan pendapat yang mengakibatkan pertentangan antara pengusaha atau gabungan pengusaha dengan pekerja/buruh atau serikat pekerja/serikat buruh karena adanya perselisihan mengenai hak, perselisihan kepentingan, perselisihan pemutusan hubungan kerja dan perselisihan antar serikat pekerja/serikat buruh dalam satu perusahaan.

2. Perselisihan hak adalah perselisihan yang timbul karena tidak dipenuhinya hak, akibat adanya perbedaan pelaksanaan atau penafsiran terhadap ketentuan peraturan perundangundangan,

perjanjian kerja, peraturan perusa-haan, atau perjanjian kerja bersama. 
3. Perselisihan kepentingan adalah perselisihan yang timbul dalam hubungan kerja karena tidak adanya kesesuaian pendapat mengenai pembuatan, dan/atau perubahan syaratsyarat kerja yang ditetapkan dalam perjanjian kerja, atau peraturan perusahaan, atau perjanjian kerja bersama.

4. Perselisihan pemutusan hubungan kerja adalah perselisihan yang timbul karena tidak adanya kesesuaian pendapat mengenai pengakhiran hubungan kerja yang dilakukan oleh salah satu pihak.

5. Perselisihan antar serikat pekerja/serikat buruh adalah perselisihan antara serikat pekerja/serikat buruh dengan serikat pekerja/serikat buruh lain hanya dalam satu perusahaan, karena tidak adanya persesuaian paham mengenai keanggotaan, pelaksanaan hak, dan kewajiban keserikatpekerjaan.

6. Serikat pekerja/serikat buruh adalah organisasi yang dibentuk dari, oleh, dan untuk pekerja/buruh baik di perusahaan maupun di luar perusahaan, yang bersifat bebas, terbuka, mandiri, demokratis, dan bertanggung jawab guna memperjuangkan, membela serta melindungi hak dan kepentingan pekerja/buruh serta meningkatkan kesejahteraan pekerja/buruh dan keluarganya.

7. Perundingan bipartit adalah perundingan antara pekerja/ buruh atau serikat pekerja/serikat buruh dengan pengusaha untuk menyelesaikan perselisihan hubungan industrial.

8. Mediasi Hubungan Industrial yang selanjutnya disebut mediasi adalah penyelesaian perselisihan hak, perselisihan kepentingan, perselisihan pemutusan hubungan kerja, dan perselisihan antar serikat pekerja/serikat buruh hanya dalam satu perusahaan melalui musyawarah yang ditengahi oleh seorang atau lebih mediator yang netral.

\subsubsection{Cara Penyelesaian Perselisihan Hubungan Industri}

a. Penyelesaian Melalui Bipartit Pasal 6 (1) Setiap perundingan sebagaimana dimaksud dalam Pasal 3 harus dibuat risalah yang ditandatangani oleh para pihak.Pasal 7(1) Dalam hal musyawarah sebagaimana dimaksud dalam Pasal 3 dapat mencapai kesepakatan penyelesaian, maka dibuat Perjanjian Bersama yang ditandatangani oleh para pihak.

b. Penyelesaian Melalui Mediasi

Pasal 8 Penyelesaian
perselisihan melaui mediasi
dilakukan oleh mediator yang berada
di setiap kantor instansi yang
bertanggung jawab di bidang
ketenagakerjaan Kabupaten/ Kota.
Pasal 10 Dalam waktu selambat-
lambatnya 7 (tujuh) hari kerja setelah
menerima pelimpahan penyelesaian


perselisihan, mediator harus sudah mengadakan penelitian tentang duduknya perkara dan segera mengadakan sidang mediasi. Pasal 11 (1) Mediator dapat memanggil saksi atau saksi ahli untuk hadir dalam sidang

mediasi guna diminta dan didengar keterangannya. (2) Saksi atau saksi ahli yang memenuhi panggilan berhak menerima penggantian biaya perjalanan dan akomodasi yang besarnya ditetapkan dengan Keputusan Menteri.

c. Penyelesaian Melalui Konsiliasi

Pasal 17 Penyelesaian perselisihan melalui konsiliasi dilakukan oleh konsiliator yang terdaftar pada kantor instansi yang bertanggung jawab di bidang ketenagakerjaan Kabupaten / Kota. Pasal 18 (1) Penyelesaian perselisihan kepentingan, perselisihan pemutusan hubungan kerja atau perselisihan antar serikat pekerja/serikat buruh hanya dalam satu perusahaan melalui konsiliasi dilakukan oleh konsiliator yang wilayah kerjanya meliputi tempat pekerja/buruh bekerja.

Penyelesaian oleh konsiliator sebagaimana dimaksud dalam ayat (1), dilaksanakan setelah para pihak mengajukan permintaan penyelesaian secara tertulis kepada konsiliator yang ditunjuk dan disepakati oleh para pihak.

\subsubsection{Hak Pekerja / Buruh yang di PHK Karena Perusahaan Pailit.}

Hak Pekerja terbagi atas hak upah dan hak selain upah seperti pesangon dan lain sebagainya. Hak upah pekerja termasuk dalam utang harta pailit .Artinya, dianggap sebagai harta pailit yang harus dibayarkan sebelum didistribusikan kepada semua kreditor termasuk kreditor separatis. Dasar hukumnya adalah pasal penjelasan pasal 95 ayat 4 undang-undang No. 13 tahun 2003.

Pekerja/Buruh yang di-PHK karena kepailitan berhak atas uang pesangon satu kali, uang penghargaan masa kerja satu kali, dan uang penggantian hak.

\subsection{PENUTUP}

\subsubsection{Kesimpulan}

1. Penyelesaian pemutusan hubungan kerja pada perusahaan yang mengalami pailit menurut UndangUndang Nomor. 37 tahun 2004 tentang kepailitan ada 2 cara yaitu :

a. Penyelesaian perselisihan dalam permasalahan hubungan industri khususnya terhadap terjadinya perselisihan pemutusan hubungan kerja diupayakan melalui penyelesaian diluar pengadilan (non litigasi). Upaya penyelesaian perselisihan di luar jalur Pengadilan Hubungan Industri (non litigasi) ini dapat dilakukan dengan penyelesaian melalui 3 cara yaitu Bipartit, Mediasi, dan Konsolidasi.

b. Pengadilan Hubungan Industri (litigasi) adalah pengadilan khusus yang dibentuk di lingkungan pengadilan negeri yang berwenang memeriksa, mengadili dan memberi putusan terhadap perselisihan hubungan industri. Berdasarkan hal tersebut, penyelesaian melalui pengadilan hubungan industri merupakan upaya yang ditempuh oleh para pihak yang mengalami perselisihan hubungan industri khususnya perselisihan pemutusan 
hubungan kerja setelah dilakukan upaya (non litigasi) Bipartit dan Mediasi maupun Konsolidasi yang di nyatakan gagal menyelesaikan perselisihan antara para pihak.

2. Penyelesaian hak pekerja pada perusahaan pailit menurut Undangundang Nomor. 13 tahun 2003 tentang ketenagakerjaan, perlindungan hukum hak-hak pekerja harus sesuai dengan ketentuan yang ada dalam pasal 156-157 UU Nomor 13 tahun 2003 yaitu pemberian uang pesangon, uang penghargaan masa kerja, dan uang penggantian hak.

\subsubsection{Saran}

1. Perlu adanya perhatian terhadap pekerja mengenai perlindungan hukum dalam pemberian hak-haknya atas pemutusan hubungan kerja karena perusahaan mengalami kepailitan, sehingga diperlukannya kesadaran dan ketaatan hukum bagi pihak perusahaan dalam pemberian hak-hak pekerjanya dalam penyelesaian segala perkara terutama dalam hukum ketenagakerjaan yang mengenai hak-hak pekerja, perlunya penyelesaian yang digunakan adalah jalur hukum non litigasi yang bertujuan untuk tetap terjalin hubungan baik antara kedua belah pihak.

2. Adanya peranan negara dalam bentuk kebijakan konkret untuk memberikan jaminan dan perlindungan terhadap hak-hak pekerja, serta diharapkan pemerintah dan lembaga legislatif untuk dapat merevisi UU kepailitan baru yang telah mengatur mengenai hak pekerja pada perusahaan pailit agar memperjelas dan mempertegas hak pekerja untuk didahulukan pembayaran utang gaji dari semua kreditor lainnya.

3. Diperlukan adanya sistem perlindungan pesangon, namun harus ada sistem asuransi yang dapat digunakan untuk meminimalisir resiko pekerja kehilangan upah akibat kepailitan dan jaminan atas pembayaran upah perlu diatur di dalam sistem jaminan sosial nasional yang sifatnya antisipatif.

\section{DAFTAR BACAAN}

\section{Buku-buku}

Andi Fariana. 2012. Aspek Legal

Sumber Daya Manusia Menurut

Hukum Ketenagakerjaan.

Jakarta: Mitra Wacana Media.

Much. $\quad$ Nurahmad. 2011

.PanduanMembuat Peraturan

dan Perjanjian dalam

Perusahaan. Pustaka Yustisia:

Jakarta.

Peter Mahmud Marzuki. "Penelitian Hukum”, Cet. 13, Kencana, Jakarta, 2017.

\section{Skripsi dan jurnal}

Ulva Febriana Rival, Di terbitkan Pada Tanggal 03 Maret 2014, "HAKPEKERJAPADAPERUSAHAAN YANGPAILIT”, Skripsi,FAKULTASHUKUM UNIVERSITAS HASANUDDIN MAKASSAR, 2014, Diakses Pada Tanggal 14 November 2019, h.1.

Erni Dwita Silambi, 19 Maret 2008, "PEMUTUSAN HUBUNGAN KERJA DITINJAU DARISEGI HUKUM”, Jurnal, Universitas Musamus Merauke, Di Akses Pada Tanggal 02 November 2019, h. 507

Peraturan Perundang-undangan Undang-Undang Dasar Negara Republik Indonesia Tahun 1945.

Undang-Undang Nomor 13 Tahun 2003 tentang Ketenagakerjaan. 
Undang-Undang Nomor 37 Tahun 2004 tentang Kepailitan dan Penundaan Kewajiban Pembayaran Utang.

Undang-Undang Nomor 2 Tahun 2004 tentang Penyelesaian Perselisihan Hubungan

Industrial. 